\title{
BUDIKDAMBER DENGAN MENERAPKAN PENJUALAN ONLINE BERBASIS E-COMERCE SEBAGAI UPAYA KETAHANAN PANGAN KELUARGA DALAM PEMANFAATAN LAHAN PERKOTAAN DIMASA PAMDEMIC COVID-19
}

\author{
Ichwan Nugroho ${ }^{1}$ \\ H Jazuli Mukhtar2 \\ Fifi Julfiati ${ }^{3}$ \\ Roy Mubarak $4^{*}$ \\ Bambang Utomo ${ }^{5}$ \\ 1,2,3,4*,5 Universitas Pamulang, Banten, Indonesia \\ dosen02686@unpam.ac.id 1 1) \\ dosen01962@unpam.ac.id ${ }^{2}$ \\ dosen01829@unpam.ac.id ${ }^{3}$ \\ dosen02685@unpam.ac.id ${ }^{*}$ \\ dosen01836@unpam.ac.id ${ }^{5}$
}

Kata Kunci: [Tridarma

Perguruan

Tinggi,Budikdamber, Media Sosial]

Published by:

Abstrak: Kemajuan teknologi saat ini sangat dimungkinkan berpengaruh terhadap bidang-bidang kehidupan lainnya, salah satunya dalam bidang pangan. Kemajuan teknologi ini bisa menjadi salah satu solusi ketahanan pangan masyarakat di masa depan, seperti pada kelompok masyarakat budidaya ikan di Kelurahan Larangan Indah. Mereka mencoba mewujudkan ketahanan pangannya dengan memelihara ikan melalui teknik Budikdamber. Selain itu, kemajuan teknologi dapat dimanfaatkan untuk memasarkan produk yang dihasilkan yaitu melalui media sosial. Media sosial telah menjadi alat penting bagi bisnis pemasaran. Dengan pemasaran lewat media sosial ini diharapkan dapat meningkatkan nilai ekonomi pada Kelompok Masyarakat Larangan Indah saat ini. Tentunya penerapan teknik budikdamber dan pemasaran melalui media sosial ini membutuhkan serangkaian pemaparan dan pelatihan untuk dapat mempraktekkannya. Kebutuhan akan pemaparan dan pelatihan ini direalisasikan melalui kegiatan Pengabdian kepada Masyarakat (PkM) yang dilakukan oleh dosen dan mahasiswa sebagai salah satu Tridharma Perguruan Tinggi.

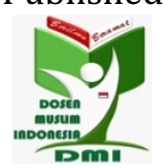

Copyright (C) 2021 The Author(s)

This article is licensed under CC BY 4.0 License

\section{(cc) BY}

https://dmi-journals.org/jai 


\section{Pendahuluan}

Kemajuan teknologi saat ini berpengaruh terhadap bidang-bidang kehidupan lainnya, salah satunya dalam bidang pangan. Guna mewujudkan ketahanan pangan di Kelompok Masyarakat Budidaya perikanan dan perkebunan, dapat dilakukan dengan memanfaatkan teknologi, yaitu budidaya ikan dan sayur dalam ember (Budikdamber). Teknik ini merupakan salah satu solusi pangan masa depan yang bisa dikembangkan dan sangat efektif digunakan di lahan terbatas seperti di perkotaan untuk memenuhi kebutuhan pangan masyarakat terutama di masa pandemi Covid-19 seperti saat ini (Susetya, I.E., 2018). Melalui Budikdamber, tak perlu repot dan khawatir untuk memenuhi kebutuhan protein hewani dan sayuran. Terlebih saat ini pemerintah Indonesia masih memberlakukan Pemberlakuan Pembatasan Kegiatan Masyarakat (PPKM) untuk memutus rantai penyebaran penyebab Covid-19.

Berkembang pesatnya kemajuan teknologi saat ini, juga dapat digunakan dengan lebih memanfaatkan media sosial untuk dapat meningkatkan nilai ekonomi pada Kelompok Masyarakat Larangan Indah saat ini. Media sosial telah menjadi alat penting bagi bisnis pemasaran. Peningkatan paparan atau eksposur dan tingkat kemunculan informasi merupakan dua manfaat utama pemasaran dalam media sosial. Kebanyakan pengguna media sosial yang menggunakan media sosial untuk mengembangkan pemasarannya.(Tobing, 2019), sehingga konsumen dapat mengetahui produk yang mereka butuhkan melalui dunia maya tersebut. Salah satu teknologi informasi media sosial yang digunakan adalah media sosial instagram, whatsapp. Satu kasus yang paling menarik, media sosial merupakan salah satu kunci efektif bagi berbagai produk untuk dipasarkan karena memungkinkan penjual berkomunikasi secara langsung dengan konsumen, selain itu media ini juga dapat mempromosikan berbagai kegiatan dan membangun kesadaran masyarakat. Dengan memanfaatkan media informasi yang luas seputar budikdamber, masyarakat dimudahkan untuk mendapatkan informasi yang ada, terutama agar dapat mengembangkan dengan usahanya, kemudian dapat memaksimalkan upayanya dengan adanya kemajuan dibidang teknologi informasi.

Pengabdian kepada Masyarakat (PkM) merupakan salah satu perwujudan dari Tri Dharma Perguruan Tinggi yaitu pengabdian masyarakat. Pengabdian merupaan suatu wujud kristalisasi dan integralisasi dari ilmu yang tertuang secara teoritis dibangku kuliah untuk diterapkan secara nyata dalam kehidupan sehari-hari di masyarakat, sehingga ilmu yang diperoleh dapat diaplikasikan dan dikembangkan dalam kehidupan masyarakat luas.

PkM ini diharapkan dapat menjadi suatu pengalaman belajar yang baru untuk menambah pengetahuan, kemampuan, dan kesadaran hidup bermasyarakat. Bagi masyarakat, kehadiran tim PkM diharapkan mampu memberikan motivasi dan inovasi dalam bidang sosial kemasyarakatan. Dalam program PkM pada kesempatan ini, kelompok masyarakat adalah salah satu tempat yang menjadi pelaksanaan kegiatan PkM ini, yaitu di Kelurahan Larangan Indah, tepatnya di wilayah RT 002/010, Kecamatan Larangan, Kota Tangerang. Di sini, minat masyarakat untuk konsumsi sayur dan ikan sangatlah tinggi. Kegiatan PKM ini mengusung tema "BUDIKDAMBER DENGAN MENERAPKAN PENJUALAN ONLINE BERBASIS E-COMERCE SEBAGAI UPAYA KETAHANAN PANGAN KELUARGA DALAM PEMANFAATAN LAHAN PERKOTAAN DIMASA PAMDEMIC COVID-19". 


\section{Metode Pelaksanaan}

Kegiatan ini telah dilaksanakan di Kelompok Masyarakat, Kelurahan Larangan Indah, Kecamatan Larangan, Kota Tangerang. Kegiatan dirancang sebagai Dharma Perguruan Tinggi yaitu pengabdian masyarakat untuk memanfaatkan Internet dan Media social dalam penerapan Budikdamber sebagai upaya dalam pemanfaatan lahan dilahan perkotaan dengan Pendidikan Masyarakat, yang bertujuan meningkatkan pemahaman serta kesadaran masyarakat. Alasan dan pertimbangan penulis dalam memilih tempat ini karena tempat ini berlatar belakang ekonomi menengah kebawah, apa lagi lokasinya ditengah perkotaan yang memiliki lahan terbatas.

Pelaksanaan kegiatan ini dilakukan selama 1 hari, pada hari Sabtu, tanggal 2 Oktober 2021, dengan jumlah peserta sebanyak kurang lebih 30 orang warga (bapak dan Ibuyang dimulai dari pukul 13.30 WIB hingga pukul 17.00 WIB. Bertempat di RT 002/010 Kelurahan Larangan Indah, Kecamatan Larangan, Kota Tangerang.

Metode dan materi kegiatan yang diberikan kepada masyarakat dalam pelatihan pemanfaatan internet dan media sosial ini adalah dengan menggunakan Pendidikan Masyarakat, dengan penjelasan sebagai berikut:

1. Pemaparan dan penjelasan materi tentang internet, media sosial, dan cara pemanfaatan yang dapat diakses untuk menambah wawasan masyarakat dalam penerapan Budikdamber dan cara pemasaran produk lewat media sosial.

2. Dengan mempraktikkan langsung bagaimana Bahan dan Alat Peralatan dan bahan yang digunakan untuk membuat Budikdamber, Yaitu seperti antara lain:
a. Ember 80 liter
b. Arang
c. Gelas plastik
d. Benih Lele
e. Bibit Kangkung
f. Solder

3. Tata Laksana Kegiatan

a. Persiapan

1) Survei Lokasi Sasaran

Kegiatan ini bertujuan untuk mengetahui kondisi lokasi sasaran, yang meliputi kondisi warga, kondisi lingkungannya dan juga mengetahui potensi yang ada dalam lokasi sasaran. Pengamatan selanjutnya adalah dengan mengidentifikasi masalah apa yang ada di lokasi tersebut dan melihat potensi yang ada dan belum dioptimalkan pemberdayaannya.

2) Perizinan Kegiatan

Kegiatan ini merupakan yang berhubungan langsung dengan masyarakat serta daerah yang ditempatinya, maka perizinan ini sangat diperlukan sebagai salah satu modal awal untuk diadakannya kegiatan ini. Secara tidak langsung, perizinan ini diperlukan sebagai kesediaan masyarakat untuk mengetahui adanya kegiatan tersebut, yang dalam hal ini diwakili oleh salah satu masyarakat setempat, untuk dapat menerima inovasi yang kami 
berikan. Selain itu, perizinan ini juga diperlukan untuk mengetahui kesediaan masyarakat untuk ikut serta dalam pengolahan budikdamber yang dilakukan pada lahan yang sedikit dilingkungan masyarakat.

3) Pengajuan Proposal Kegiatan

Proposal Kegiatan ini dilakukan sebagai penyampaian ide dalam kegiatan serta penjelasan secara rinci mengenai latar belakang kegiatan, gambaran umum, lokasi sasaran, tata laksana program, jadwal kegiatan hingga anggaran dana yang dibutuhkan dalam kegiatan, mengingat tanpa adanya proposal dan persetujuan maka kegiatan ini tidak akan berlangsung.

4) Survei penyediaan alat dan bahan yang dibutuhkan

Dalam Tahap Kegiatan ini bertujuan untuk mengetahui tempat yang menyediakan alat dan bahan yang diperlukan untuk memulai pelaksanaan kegiatan ini, mengingat data yang diperoleh dari kegiatan ini berhubungan langsung dengan anggaran dana yang diperlukan.

5) Pembuatan Materi

Dalam Penyampaian Pembuatan materi penyampaian diperlukan karena dalam kegiatan penyuluhan dan pelatihan bagaimana mengenai cara pemanfaatan internet dan media social dalam penerapan budidamber sangat diperlukan untuk wawasan yang diperlukan guna memulai kegiatan tersebut.

b. Pelaksanaan

1) Pembelian alat dan bahan yang digunakan

Kegiatan ini bertujuan sebagai mendapatkan alat dan bahan yang diperlukan untuk memalai kegiatan berlangsung.

2) Pembuatan susunan acara

Kegiatan ini bertujuan untuk membuat rancangan acara dari kegiatan yang akan dilaksanakan agar semua kegiatan yang direncanakan dapat berjalan dengan baik.

3) Pelatihan Trial

Kegiatan pelatihan ini bertujuan untuk memperkenalkan tata cara atau model pelaksanaan dalam pemanfaatan media internet dan media social dalam penerapan budikdamber. Dalam kegiatan ini disediakan materi untuk peserta penyuluhan agar pemahaman masyarakat tentang prosedure atau langkah-langkah yang harus dilakukan dalam pembuatan media dan perawatan budikdamber dan media social sebagai media dalam memasarkan hasil dari penerapan budikdamber (Maharani, Helmiah and Rahmadani, 2021)

4) Praktek Teknik pembuatan budidamber

Kegiatan praktek teknik pembuatan budidamber dilakukan di pekarangan rumah salah warga. Di dalam kegiatan tersebut, warga akan diberitahukan mengenai cara pembuatan budikdamber ini sehingga warga dapat ikut berpartisipasi dalam kegiatan tersebut.

5) Pelatihan Pembuatan budikdamber. 
6) Pembuatan budikdamber ini adalah sebagai berikut:

a. Persiapan Wadah

- Ember baru dibeli untuk budidaya wajib dibersihkan (sterilisasi) terlebih dahulu (cuci hingga bersih dengan sedikit detergen cair), lalu bilas hingga $3 x$ dengan air bersih;

- Ember ditaruh di tempat yang teduh (tapi tetap terkena sinar matahari), di atas alas berupa susunan batu bata satu lapis;

- Isi ember dengan air sampai penuh (sisakan $10 \mathrm{~cm}$ dari bibir ember). b. Persiapan Media Tanam Sayuran

- Lubangi gelas plastik bagian bawah dan samping dengan solder/paku/jarum secukupnya (untuk peresapan air) serta 2 (dua) bagian atas untuk mengkaitkan kawat di ember

- Potong kawat sepanjang 12-17 cm dan dibentuk huruf "u" untuk dipasang pada gelas plastik untuk dikaitkan pada ember

- Masukkan arang yang dipotong kecil-kecil dan busa bekas yang sudah diiris melintang dua arah pada gelas plastik secukupnya

- Masukkan bibit sayuran pada gelas yang sudah diberi arang dan busa kemudian gantungkan ke sekeliling bibir ember.

c. Pasca Pelaksanaan

1) Pendampingan Kegiatan pendampingan dilaksanakan setelah pelatihan. Melalui kegiatan ini diharapkan masalah yang dihadapi warga terkait dengan pelatihan dapat dicari dan dipecahkan bersama.

2) Evaluasi dan pelaporan Kegiatan ini beruapa monitoring yang dilaksanakan oleh tim pelaksana untuk mengetahui kelanjutan dari hasil pelatihan. Kegiatan tersebut akan menjadi dasar dalam pembuatan laporan Pengabdian Kepada Masyarakat ini. 


\section{Hasil dan Pembahasan}

Hasil dan pembahasan yang dicapai dari kegiatan pelatihan ini adalah:

1. Masyarakat mampu mencari ilmu dan informasi melalui referensi situs-situs budikdamber yang telah penulis berikan untuk meningkatkan kemampuan dan wawasan masyarakat yang bersangkutan. Masyarakat juga diharapkan mampu mencari referensi-referensi situs lain yang berhubungan dengan penerapan Budukdamber.

2. Pemanfaatan Aplikasi media sosial ini sangat bermanfaat bagi kelompok masyarakat, tak terkecuali di RT002/010 Larangan Indah. Bagi RT002/010 Larangan Indah media sosial berguna sekali dalam penyebaran informasi. Masyarakat bisa membagikan berbagai informasi yang berguna bagi pembacanya. Media sosial yang digunakan oleh RT002/010 Larangan Indah adalah Whatsaap, Instagram, Facebook kegiatan-kegiatan masyarakat dan informasi-informasi lain yang cukup membantu pembacanya mengetahui hal-hal yang terkait dengan RT002/010 Larangan Indah.

3. Pemanfaatan Aplikasi Media Sosial untuk Promosi di RT002/010 Larangan Indah

Hal yang pentingnya adalah kegiatan promosi, yang juga diperlukan oleh kelompok masyarakat RT002/010 Larangan Indah. Masyarakat mampu menggunakan sosial media dengan baik dan bijak serta mampu mengembangkan usaha dan promosi melalui sosial media dengan beberapa aplikasi media social seperti Whatsaap, Instagram, Facebook dalam penerapan budikdamber dengan menjual hasil seperti sayur, ikan, ataupun media budikdamber.

Adapun susunan acara pelaksanaan kegiatan PkM adalah sebagai berikut:

Tabel 1. Susunan Acara Kegiatan Pengabdian Masyarakat

\begin{tabular}{|c|c|c|}
\hline \multicolumn{3}{|c|}{ SUSUNAN ACARA } \\
\hline Waktu & Acara & $\begin{array}{c}\text { Keterangan/Penanggung } \\
\text { Jawab }\end{array}$ \\
\hline $13.30-14.00$ & Persiapan \& Registrasi Peserta & Mahasiswa \\
\hline $14.00-14.10$ & $\begin{array}{l}\text { Pembukaan dan Perkenalan } \\
\text { Panitia }\end{array}$ & Ibu Fifi Julfiati \\
\hline $14.10-14.30$ & Sambutan & $\begin{array}{l}\text { a. Ketua Pengabdi } \\
\text { b. Bpk Lurah \& Ketua RT }\end{array}$ \\
\hline $14.30-15.30$ & $\begin{array}{l}\text { Sesi } 1 \\
\text { Pembahasan Internet dan } \\
\text { Media Sosial }\end{array}$ & $\begin{array}{l}\text { a. Bpk. Bambang Utomo } \\
\text { b. Hans Somasido F.D }\end{array}$ \\
\hline $15.30-16.40$ & $\begin{array}{l}\text { Sesi } 2 \\
\text { Penerapan Budikdamber }\end{array}$ & $\begin{array}{l}\text { a. Bpk. Ichwan Nugroho } \\
\text { b. Bpk. Roy Mubarak } \\
\text { c. Irsanto }\end{array}$ \\
\hline $16.40-16.50$ & $\begin{array}{l}\text { Sesi } 3 \\
\text { Dokumentasi }\end{array}$ & $\begin{array}{l}\text { a. Dani Muliansyah } \\
\text { b. Effendy Candra S } \\
\text { c. Muammar Syabani.A } \\
\text { d. Pajar Septian }\end{array}$ \\
\hline $16: 50-17: 00$ & Do'a dan Penutupan & Endah Sumiati \\
\hline
\end{tabular}


Vol. 1. No. 4 Desember 2021

Berikut ini kegiatan PKM yang didokumentasikan :

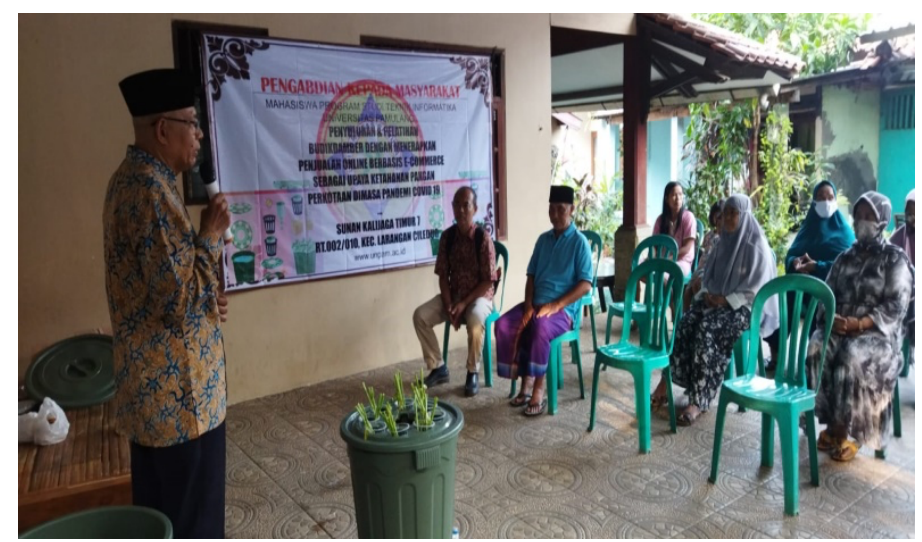

Gambar 1. Sambutan dari Bpk Dosen/Ketua Pengabdi

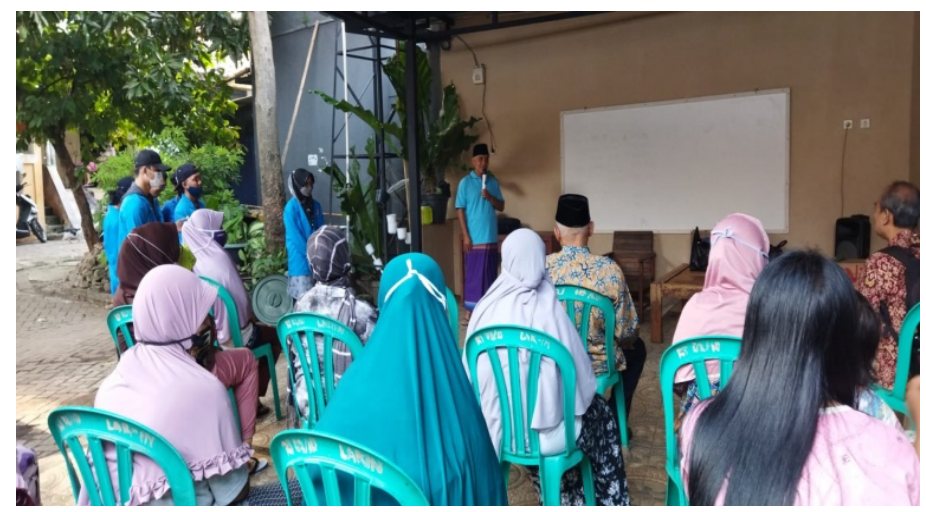

Gambar 2. Sambutan Dari Bpk Ketua RT

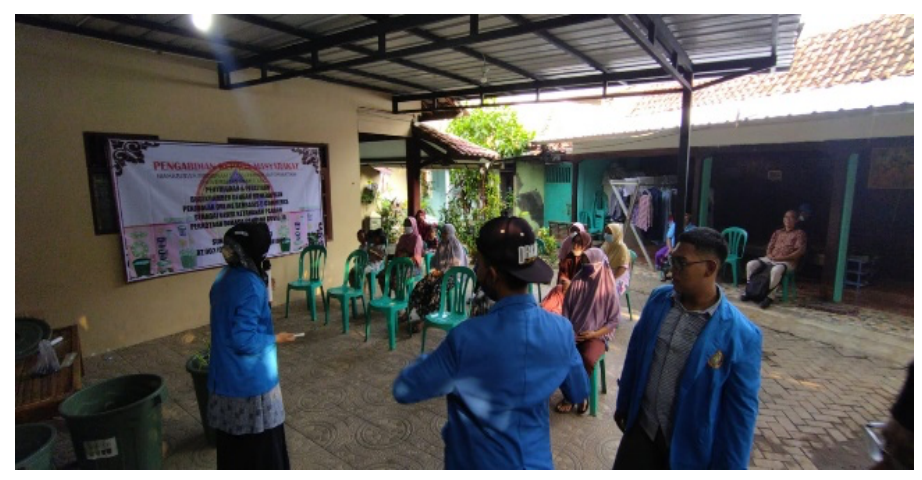

Gambar 3. Penjelasan Tentang Pemanfaatan Internet Dalam Penerapan Budikdamber

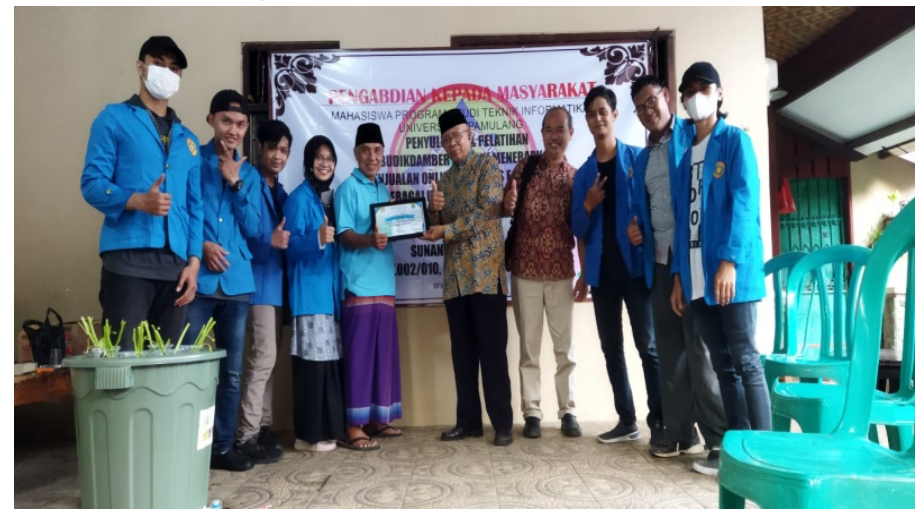

Gambar 4. Foto Penyerahan Sertifikat Untuk Ketua RT Setempat 


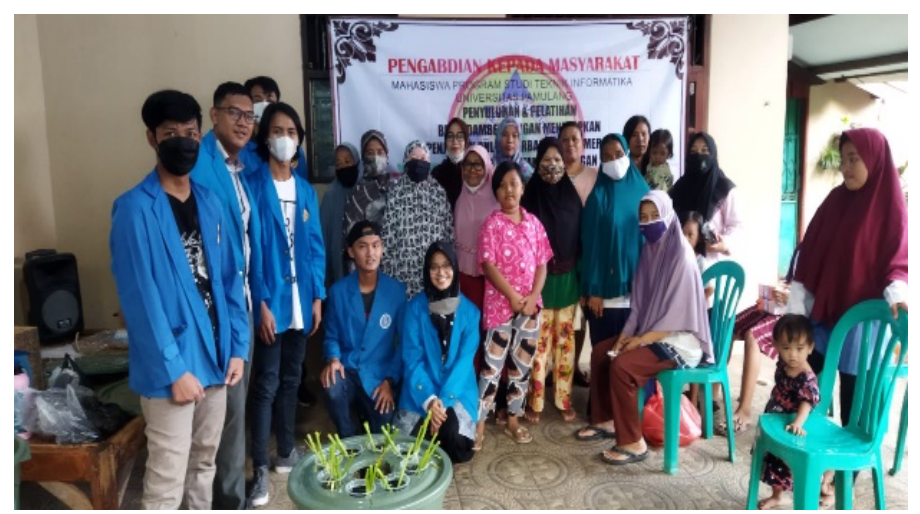

Gambar 5. Foto Bersama Sebagian Peserta Pelatihan Masyarakat Larangan Indah

Kegiatan Pengabdian kepada Masyarakat ini diharapkan dapat memberikan manfaat kepada masyarakat Kelurahan Larangan Indah, melalui pemberian pengetahuan tentang perkebunan dan perikanan sebagai upaya pengelola pangan keluarga dan memiliki nilai ekonomi yang baik melalui media sosial; penyediaan secara mandiri kebutuhan pokok sayuran seperti kangkung, bayam, sawi, selada, sawi atau caisin; dan penyediaan secara mandiri kebutuhan pokok hewani seperti ikan lele, nila, gabus, patin, gurame.

\section{Kesimpulan}

Pelaksanaan kegiatan Pengabdian Kepada Masyarakat (PkM) tahun ajaran 2020/2021 diselenggarakan di RT002/ RW010 Kel. Larangan Indah, Kota.Tangerang, yang beralamat di Jl. Sunan Kalijaga7, Larangan Indah, Kota Tangerang. Kegiatan tersebut dilaksanakan pada hari Sabtu, 02 Oktober 2021, dengan tema "Penyuluhan Dan Pelatihan Budikdamber Dengan Menerapkan Penjualan Online Berbasis E-Commerce Sebagai Upaya Ketahanan Pangan Keluarga Dalam Pemanfaatan Lahan Perkotaan Dimasa Pamdemic Covid-19", dilakukan melalui tatap muka langsung, dengan peserta para warga masyarakat Kelurahan Larangan Indah. Kegiatan ini berjalan dengan lancar, sukses, dan penuh antusias dari para peserta yang hadir.

Hasil dari pelaksanaan kegiatan pengabdian kepada masyarakat ini peserta dapat meningkatkan kemampuan dalam memanfaatkan lahan sempit dalam membuat Budikdamber dan memberikan pengetahuan kepada masyarakat bagaimana memanfaatkan media sosial seperti Whatsaap, Instagram, Facebook sebagai sarana promosi penjualan digital dalam mempraktekan penerapan budikdamber pada masyarakat, dan diharapkan bisa mengimplementasikannya dalam masyarakat setempat maupun masyarakat sekitar.

Berdasarkan hasil dari kegiatan pengabdian kepada masyarakat, saran yang dapat kami berikan adalah sebagai berikut :

1. Peserta mempunyai koneksi internet pada smartphone yang akan mereka gunakan dalam pelatihan.

2. Panitia hendaknya mempersiapkan lagi data peserta yang hadir dalam kegiatan. 
Kegiatan pengabdian bertema Budikdamber diharapkan tidak hanya dilakukan di RT002/10 Larangan indah tetapi di lokasi lain supaya masyarakat perkotaan yang memiliki pengetahuan dan informasi serta memiliki wadah untuk menyalurkan hobinya..

\section{Ucapan Terimakasih}

Penulis dengan segala kerendahan hati menyampaikan ucapan terima kasih kepada Bapak Achmad Udin Zailani, S.Kom.,M.Kom selaku Ketua Program Studi Teknik Informatika Program Sarjana Universitas Pamulang, Bapak H. Naman, M.M., selaku lurah Kelurahan Larangan Indah, Kecamatan Larangan, Kota Tangerang.

\section{Referensi}

Andhikawati, A., Handaka, A. A. and Dewanti, L. P. (2021) 'Penyuluhan Budidaya Ikan dalam Ember (Budikdamber) di Desa Sukapura Kecamatan Dayeuhkolot Kabupaten Bandung', Farmers: Journal of Community Services, 2(1), p. 47. doi: 10.24198/fjcs.v2i1.31547.

Maharani, D., Helmiah, F. and Rahmadani, N. (2021) 'Penyuluhan Manfaat Menggunakan Internet dan Website Pada Masa Pandemi Covid-19', Jurnal Pengabdian Masyarakat Informatika, 1(1), pp. 1-7. doi: 10.25008/abdiformatika.v1i1.130.

Susetya, I.E., Z. A. H. (2018) 'Aplikasi Budikdamber ( Budidaya Ikan Dalam Ember ) Untuk Keterbatasan Lahan di Kota Medan', Abdimas Talenta, 3(2), pp. 416-420.

Tobing, S. M. (2019) 'Pemanfaatan Internet Sebagai Media Informasi Dalam Kegiatan Belajar Mengajar Pada Mata Kuliah Pendidikan Pancasila', JURNAL PEKAN : Jurnal Pendidikan Kewarganegaraan, 4(1), pp. 64-73. doi: 10.31932/jpk.v4i1.376.

Nadya Adharani1*, Kadarwan Soewardi2, Agung Dhamar Syakti3, Sigid Hariyadi2. 2016. Manajemen Kualitas Air Dengan Teknologi Bioflok: Studi Kasus Pemeliharaan Ikan Lele (Clarias Sp.). Jurnal Ilmu Pertanian Indonesia (JIPI), April 2016 Vol. 21 (1): 35-40 ISSN 0853- 4217

Nofi A. Rokhmah, Chery Soraya Ammatillah, dan Yudi Sastro. 2014. Mini Akuaponik untuk Lahan Sempit di Perkotaan. Buletin Pertanian Perkotaan Volume 4 Nomor 2, 2014 | 14. Balai Pengkajian Teknologi Pertanian Jakarta

BSN. 2000. Benih Ikan Lele Dumbo (Clarias gariepinus x C. Fuscus) Kelas Benih Sebar. SNI : 01-6484.2- 2000

BSN. 2000. Produksi Benih Ikan Lele Dumbo (Clarias gariepinus x C. Fuscus) Kelas Benih Sebar. SNI : 01- 6484.2-200 